\title{
C-type lectins in HIV-1 infection
}

\author{
Teunis BH Geijtenbeek \\ From Frontiers of Retrovirology 2011 \\ Amsterdam, The Netherlands. 3-5 October 2011
}

\begin{abstract}
Adaptive immune responses by dendritic cells (DCs) are controlled by pattern recognition receptors such as Toll-like receptors (TLRs) and C-type lectins. C-type lectins interact with carbohydrate structures on pathogens. Upon pathogen binding, C-type lectins trigger signaling pathways that induce specific cytokines to dictate $\mathrm{T}$ cell polarization. Thus, C-type lectins are crucial in tailoring immune responses to pathogens. HIV-1 is recognized by the C-type lectin DC-SIGN. Previous data have shown that DC-SIGN is involved in HIV-1 transmission by DCs. DCs efficiently capture HIV-1 and transmit the virus to $\mathrm{T}$ cells. However, recent data show that DC-SIGN also induces signaling that shape adaptive immune responses. Here I will discuss the molecular signaling pathways induced by DC-SIGN that are involved in adaptive immunity to HIV-1. Notably, HIV1 hijacks the signaling by DC-SIGN and TLR8 for its own replication and transmission. The subversion of these crucial immune signaling pathways by HIV-1 and the consequences for HIV-1 infection will also be discussed.
\end{abstract}

Published: 3 October 2011

Submit your next manuscript to BioMed Central and take full advantage of:

- Convenient online submission

- Thorough peer review

- No space constraints or color figure charges

- Immediate publication on acceptance

- Inclusion in PubMed, CAS, Scopus and Google Scholar

- Research which is freely available for redistribution 